\title{
Penerapan pemberdayaan masyarakat pelaku usaha lopek bugih melalui perlindungan hukum dan inovasi usaha Desa Palung Raya Kecamatan Tambang Kabupaten Kampar Riau
}

\author{
Emilda Firdaus, Firdaus, Hengky Firmanda, Deby Kurnia, \& Sukamarriko Andrikasmi* \\ Fakultas Hukum, Universitas Riau \\ *sukamarriko@lecturer.unri.ac.id
}

\begin{abstract}
Abstrak. Desa Palung Raya memiki potensi kuliner yang dapat dikembangkan seperti lopek bugih, lopek bugih merupakan makanan khas tradisional yang dimiliki Kabupaten Kampar, makan ini merupakan makan olahan tepung beras ketan yang diberikan isi kelapa parut yang diberi gula pasir. Tujuan kegiatan ini untuk mendukung program perguruan tinggi melalui dalam mewujudkan tridarma perguruan tinggi disamping itu juga untuk meningkatan ekonomi pelaku usaha lopek bugih. Metode penerapan yang diberikan dengan memberikan sosialisasi dan pendampingan dalam pengurusan legalitas usaha, dan menciptakan inovasi rasa terbaru lopek bugih yang selama ini hanya terdiri satu rasa saja, , kegiatan tersebut dilakukan dengan melibatkan langsung kelompok usaha yang telah memenuhi unsur.

Pemberdayaan pelaku usaha lopek bugih ini menghasilkan legalitas usaha dan inovasi variasi rasa lopek bugih.
\end{abstract}

Kata kunci: pemberdayaan, pelaku usaha, lopek bugih

Abstract. Palung Raya village has culinary potential that can be developed such as lopek bugih, lopek bugih which is a traditional food belonging to Kampar Regency, this meal is a meal of processed glutinous rice flour which is filled with grated coconut filled with sugar. The purpose of this activity is to support higher education programs through realizing the three principles of higher education as well as improving the economy of lopek bugih business actors. The method of application is provided by providing socialization and assistance in managing business legality, and creating the latest innovative taste of lopek bugih which so far only consists of one taste, these activities are carried out by directly involving business groups that have met the elements. The empowerment of lopek bugih business actors resulted in business legality and innovation in variations of lopek bugih.

Keywords: empowerment, business actors, lopek bugih

To cite this article: Firdaus, E., Firdaus., H. Firmanda., D. Kurnia., \& S. Andrikasmi. 2020. Penerapan pemberdayaan masyarakat pelaku usaha lopek bugih melalui perlindungan hukum dan inovasi usaha Desa Palung Raya Kecamatan Tambang Kabupaten Kampar Riau. Unri Conference Series: Community Engagement 2: 10-15. https://doi.org/10.31258/unricsce.2.10-15

(C) 2020 Authors

Peer-review under responsibility of the organizing committee of Seminar Nasional Pemberdayaan Masyarakat 2020 


\section{PENDAHULUAN}

Potensi yang dimiliki Desa Palun Rraya Kecamatan Tambang Kabupaten Kampar dapat dikembang dan di kelola untuk kepentingan masyarakatnya, terlebih hampir $40 \%$ masyarakat desanya adalah mereka yang berpendidikan menengah ke atas. Secara geografi Desa Palung Raya yang berada di jalan lintas antar Provinsi Riau dan Provinsi Sumatera Barat tentu akan menjadi peluang besar bagi masyarakat desa untuk mengambil moment sehingga dalam sektor kuliner yang dapat mendatangkan keuntungan bagi masyarakat. Kreatifitas masyarakat desa juga tidak dapat di kesampingkan sebab banyak masyarakat desa yang menekuni berbagai macam usaha rumahan yang sampai saat ini terus tekun untuk berjualan di jalan lintas tersebut yaitu yang dikenal dengan lopek bugi. Keseluruhan kemampuan masyarakat desa sepenuhnya sampai saat ini belum terekola dengan baik dan memerlukan pola yang strategis dan terarah sehingga memerlukan pembinanan dan pemberdayaan untuk masyarakat desa.

Pemberdayaan dalam kamus besar bahasa Indonesia adalah proses, cara, perbuatan memberdayakan (KBBI, 2003), pemberdayaan masyarakat akan tepat sasaran sesuai dengan potensi yang ada di desa tersebut, Desa Palungraya memiki potensi kuliner yang dapat dikembangkan seperti lopek bugih, lopek bugih merupakan makanan khas tradisional yang dimiliki Kabupaten Kampar, makan ini merupakan makan olahan tepung beras ketan yang diberikan isi kelapa parut yang diberi gula pasir. Pengelolaan dan pengembangan usaha lopek bugi sangat diperlukan diperlukan, hal ini agar tidak adanya hal yang monoton dalam menciptakan ide-ide produk yang dihasilkan, sama halnya setiap produk akan lebih bisa menembus pasar yang lebih luas jika produk tersebut telah memiliki legalitas usaha. Legalitas usaha dalam lopek bugih dapat saja berupa Hak Atas Kakayaan Intelektual dan dalam bentuk perizinan lainnya.

Bagi pelaku usaha untuk memulai usahanya perlu memikirkan perlindungan Hak Kekayaan Intelektual (selanjutnya disebut HKI). Jikalau, para pelaku usaha tidak memikirkan perlindungan HKI, maka kary a para pelaku usaha dapat mudah terjadi pelanggaran HKI. Oleh karena itu, pada masa awal memulai bisnisnya, mereka seharusnya sudah memberikan perlindungan HKI-nya, sebab HKI sejatinya dapat menjadi aset berharga yang bisa menyelamatkan perusahaan di masa-masa sulit. HKI sejatinya adalah hak yang muncul dari hasil oleh pikir atau kreasi manusia yang pada akhirnya menghasilkan suatu produk atau proses yang berguna bagi manusia. Dalam dunia bisnis, HKI bisa menjadi elemen penting karena dapat memberikan keunggulan berkompetisi ketika bermain di pasar yang dibidik bagi pemiliknya. Bahkan, tidak menutup kemungkinan pula HKI ini dapat menjadi pemicu untuk memunculkan berbagai inovasi baru bagi perusahaan yang pada akhirnya dapat menguntungkan publik juga para pelaku usaha itu sendiri, misalnya dalam menghadapi perdagangan bebas ASEAN (Priambada, 2020).

Di Indonesia, usaha mikro kecil dan menengah (selanjutnya di dalam tulisan ini menggunakan istilah UMKM) memiliki kontribusi yang cukup besar dalam perluasan kesempatan kerja dan penyerapan tenaga kerja. UMKM bisa juga dikatakan sebagai motor penggerak perekonomian di Indonesia. Pada tahun 2016 jumlah pelaku UMKM di Indonesia dilaporkan mencapai 49 juta dan diprediksi menyerap lebih dari 107 juta tenaga kerja dan kontribusi sektor UMKM terhadap produk domestik bruto (PDB) pun semakin meningkat dalam lima tahun terakhir di mana Kementerian Koperasi dan Usaha Kecil Menengah mencatat lonjakan dari 57,84 persen menjadi 60,34 persen (Gunandi, 2020).

Menurut Aswas (2014: 58-60), dalam kegiatan pemberdayaan khususnya yang ditujukan kepada masyarkat, aparat/agen pemberdayaan perlu memegang beberapa prinsip dalam pemberdayaan masyarakat, yang menjadi acuan dalam pelaksanaan sehingga kegiatan dapat berjalan dengan benar dan tepat, sesuai dengan hakikat dan konsep pemberdayaan. Hal ini bertujuan agar masyarakat dapat menerima dengan baik tampa adanya paksaan. Kemudian Pemberdayaan masyarakat (empowerment) merupakan sebagai model pembangunan berakar kerakyatan adalah upaya untuk meningkatkan harkat dan martabat sebagian masyarakat kita yang masih terperangkap pada kemiskinan dan keterbelakangan (Noor, 2011).

Pembangunan pedesaan merupakan hal yang sangat mutlak untuk dilakukan sebab desa merupakan gerbang pertama hadirnya Negara dalam bermasyarakat, majunya desa akan terasa langsung oleh masyarakat sebagai penghuni desa tersebut, maka setiap mereka yang berkewajiban untuk memajukan desa haruslah senantias bisa dan mampu menciptakan ide-ide yang kreatif sehingga pembangunan desa segera tercapai, baik pembangunan sumber daya manusianya dan pembangunan dengan pemamfaatan sumber daya alamnya. Pembangunan pedesaan saat sekarang tidak mesti terfokus kepada bidang pertanian dan perkebunan saja, melainkan juga pada sektor-sektor potensi desa lainnya.

Program inovasi produk usaha bertujuan untuk meningkatkan kualitas usaha itu sendiri melalui berbagai hasil variasi produk yang lebih inovatifdan peka terhadap pertumbuhan ekonomi pedesaan serta membangun 
kapasitas pasar produk itu sendiri yang berkelanjutan untuk meningkatkan kesejehteraan sosial-ekonomi masyarakat dan kemandirian Desa, sesuai dengan arah dan kebijakan Kementerian PDTT. Pembangunan ekonomi juga dapat diartikan sebagai proses yang menyebabkan pendapatan perkapita penduduk dalam suatu Negara meningkat dalam jangka waktu panjang (Rafanna \& Sukarno, 2017).

Permasalahan yang ditemukan oleh pelaku usaha lopek bugih Desa Palung Raya Kecamatan Tambang Kabupaten Kampar sampai saat ini adalah bagaimana cara untuk dapat melegalkan usahanya dalam sektor hukum sehingga lebih bisa menembus pasar nasional dan internasional, kemudian rasa yang ditawarkan hanya terfokus satu rasa, seharusnya pelaku usaha lopek bugih harus juga berani berinovasi dalam menciptakan variasi rasa baru sehingga membuat pembeli selalu penasaran dan ingin mencobanya.

\section{METODE PENERAPAN}

Penerapan dan pemberdayaan yang akan diberikan kepada masyarakat sasaran dalam kegiatan pengabdian kepada masyarakat yang akan dilakukan dengan memebrikan sosialisasi dan pendampingan dalam pengurusan legalitas usaha, dan menciptakan inovasi rasa terbaru lopek bugih yang selama ini hanya terdiri satu rasa saja, kegiatan tersebut dilakukan dengan melibatkan langsung kelompok usaha yang telah memenuhi unsur dan ketentuan oleh instansi terkait.

\section{HASIL DAN KETERCAPAIN SASARAN}

Pada konsideran Undang-undang Otonomi Daerah Nomor 32 Tahun 2004 dalam melaksanakan otonomi daerah untuk mewujudkan kesejahteraan rakyat dapat melalui: 1. Pelayanan Masyarakat, 2. Pemberdayaan, dan 3. Peran serta dan partisipasi masyarakat Pemberdayaan masyarakat menjadi sangat penting dan merupakan bagian dari usaha peningkatan perekonomian masyarakat melalui potensi desa yang ada. Potensi desa sangat memiliki peran strategis dalam memajukan desa yang dimulai dari peran aktif masyarakatnya sendiri dan dari lingkungan keluarga. Desa maju bila semua pihak turut serta didalamnya, masyarakat yang mandiri mencerminkan desa yang mandiri sehingga kemaslahatan desa akan terwujud dengan dimulai dari lingkungan terkecil.

Desa yang mandiri harus diikuti dengan peran serta dan kekompakan seluruh masyarakatnya, berikut beberapa jenis usaha dalam menciptakan desa yang mandiri melalui pemberdayaan masyarakatnya, yaitu:

1. Pemberdayaan sumber daya alam desa;

Setiap wilayah desa tentu memiliki kekayaan alam atau sumber daya alamnya, sebagai desa yang mandiri pengelolaan tersebut haruslah transparan, berkesinambungan dan benar-benar untuk kemakmuran masyarakat dan pengelolaan desa sesuai dengan kesepakatan masyarakat desa bersama;

2. Pemberdayaan kelompok-kelompok masyarakat;

Dalam masyarakat desa tentu memiliki organ-organ pengelola pemerintahan yang resmi seperti Kepala Desa, Sekretaris Desa, Kepala Dusun, Ketua Rukun Warga,dan atau Rukun Tetangga atau nama lainnya yang disesuaikan dengan keadaan wilayah sebagaimana yang telah diatur dalam undang-undang. Kemudian disamping organ resmi desa tentu mempunyai kelompok masyarakat yang dibentuk berdasarkan kepercayaan, kelompok suku, kelompok budaya, kelompok kerja, dan kelompok lingkungan keluarga, sehingga dalam hal ini pemerintahan desa tentu akan dapat lebih mudah melaksanakan atau meyalurkan kegiatan pemberdayaan yang telah di susun ataupun yang akan di susun sesuai kebutuhan.

3. Pemberdayaan sosial;

Setiap manusia tentu memilik rasa sosial dalam bermasyarakat, telebih masyarakat desa akan memiliki rasa sifat sosial yang lebih erat daripada masyarakaat perkotaan. Pemberdayaan sosial merupakan sebagai pemicu rasa gotong royong antara sesama warga sehingga menciptakan suatu pola rasa persaudaraan dan kekeluargaan yang kuat dalam menangani permasalahan desa dan memikirkan bersama untuk kemajuan desa; 
Pelaksanaan pemberdayaan masyarakat Desa Palun Raya, Kecamatan Tambang, Kabupaten Kampar, khusus bagi pelaku usaha lopek bugih meliputi dalam beberapa tahapan, yaitu:

\section{Tahapan Sosialisasi}

Dalam tahapan ini pelaku usaha diberikan pengetahuan tentang:

a. Hukum, bisnis, dan ekonomi, sebagai pengusaha makanan tradisional yang berdomisili/ beralamat di jalan raya Negara Riau dan Sumatera Barat, pelaku usaha harus dapat juga memahami dan mengerti tentang hukum bisnis, hukum ekonomi sebab untuk meningkatkan dan mengembangkan usaha mutlak diperlukan pengaturan dan keseimbangan antara hukum, bisnis, dan ekonomi. Usaha yang diliputi dengan hukum akan memberikan rasa aman bagi setiap pengusahanya terlebih apabila adanya singkronisasi antara hukum bisnis dan hukum ekonomi.

b. Hukum Perjanjian/ Hukum Perikatan, pengaturan dan praktek hukum perjanjian/hukum perikatan dalam menjalankan usaha menjadi pelengkap sebagai prinsip kehati-hatian dalam bermitra dengan orang atau pengusaha lainnya, sebab dokumen tersebut akan bertindak sebagai jaminan akan kerjasama yang telah mereka sepakati bersama.

c. Inovasi Usaha Industri Makanan, makanan yang bervariasi akan dapat memacu rasa penasaran konsumen untuk ingin segera mencicipinya, sebab bagaimanapun makan merupakan kegiatan yang memang harus setiap hari dilaksanakan guna untuk menambah daya tahan dan kesehatan tubuh, sehingga inovasi merupakan jalan keluar akan konsumen/ langgaran agar merasa tidak bosan dengan produk yang hanya itu-itu saja.

d. Pengembangan Usaha dan Penguatan Ekonomi Masyarakat, sebagai makanan khas oleh-oleh dari Kabupaten Kampar dan Riau umumnya, pelaku usaha lopek bugih juga harus memperhatikan pengembangan usahanya kedepan, kemudian pengembangan usaha tersebut mestilah berkesinambungan yang nantinya dapat meningkatkan ekonomi keluarga dan kesejahteraan masyarakat umumnya. Dalam pengembangan usaha lopek bugih, sebagai pelaku usaha dapat melakukan:

i. Membuka diri terhadap pola kebutuhan konsumen;

ii. Membuat produk lebih moderen dan kekinian;

iii. Berani membentuk jaringan bisnis dan jaringan kerjasama sesame pelaku usaha;

iv. Membuka cabang atau stand ditempat-tempat acara;

v. Memampilkan khas daerah pada produk atau pada kemasan lopek bugih; dan

vi. Jika produk telah berkembang dan bermutu maka pelaku usaha wajib sepakat dan setuju untuk memulai harga baru.

e. Teknik Pemasaran Online, kemajuan teknologi tidak dapat dipungkiri dan tidak dapat pula untuk dihentikan, sebab dalam situasi lainnya, jika penerapan teknologi terlaksana, pelaku usaha lopek bugih juga akan dihadapkan dengan pelayanan konsumen dan relasi secara online, artinya pembeli tidak akan lansung melihat produk yang dibelinya, melainkan hanya memilih foto produk pada gambar yang tersedia, hal inilah yang membuat pelaku usaha lopek bugi selama ini takut dan khawatir dalam penjualannya. Kemudian kondisi masyarakat setempat dalam pengelolaan atau manajemen usaha lopek bugih, masih tergolong sangat sederhana dan manual. Keberadaan situasi ini tidak terlepas dari tingkat pendidikan pengusaha lopek bugih yang hampir seluruhnya hanya sampai sekolah menengah tingkat atas. Pengelolaan dan pengembangan yang kreatif serta berbasis teknologi sangat mutlak diperlukan oleh pelaku usaha lopek bugih di Desa Palung Raya Kecamatan Tambang Kabupaten Kampar.

f. Kesiapan Usaha dalam menghadapi tantangan termasuk Covid-19, pandemi Covid-19 seakan telah menjadi tantangan untuk semua sektor kehidupan pada tahun 2019, sehingga setiap orang dituntut untuk lebih memperhatikan tentang pentingnya kebersihan diri dan lingkungannya, terlebih lagi Covid-19 cara penularanya sangat mudah, cepat dan dikenal sangat mematikan, terlebih lagi sampai saat sekarang vaksin penyembuhannya belum tersedia. Berikut usaha yang dapat diterapkan oleh pelaku usaha lopek bugih dalam masa pandemic Covid-19 adalah:

i. Menerapkan dan mematuhi protokol kesehatan sesuai dengan anjuran pemerintah;

ii. Memberikan keyakinan kepada konsumen bahwa cara pengelolaan dan pengemasan produk yang dijual dijamin bersih dengan cara mengedukasi konsumen pada saat mereka membeli, hal ini dapat perlihatkan dengan berupa gambar cara pembuatannya;

iii. Tidak memproduksi produk dalam jumlah banyak, hal ini disebabkan karena gerak bebas masyarakat terbatas yaitu dengan bekerja, beribadah dan belajar dari rumah; 
iv. Menciptakan lingkungan, dan alat produksi usaha yang bersih dengan selalu membersihkan saat setelah produksi dan akan mulai produksi;

v. Memastikan bahan baku yang digunakan adalah tetap yang terbaik dan dengan komposisi yang aman bagi kesehatan konsumen;

vi. Menyediakan akses pembayaran mandiri/ digital yang tidak mesti bersentuhan antara pelayan toko dan konsumen.

g. Hak Atas Kekayaan Intelektual (HAKI) dalam Bisnis, pentingnya akses akan HAKI merupakan keperluan yang harus dipatuhi oleh setiap mereka yang mempunyai usaha, memiliki HAKI akan lebih menjamin bahwa setiap produk dan usaha yang dimiliki akan dapat terjaga dan dipertahakan terhadap siapapun juga yang ingin memiliki haknya secara illegal atau bertentangan dengan hukum, untuk usaha lopek bugih HAKI dapat saja berupa Hak Cipta, Merek Usaha, dan Rahasia Dagang.

h. Hukum Perusahaan, dan Praktek Tata Cara Pendirian Persekutuan Komanditer (CV), Perseroan Terbatas, dan Industri Rumah Tangga;

Tidak mustahil usaha lopek bugih akan berkembang dan bahkan dapat menjadi sebuah perusahaan yang berbadan hukum dan resmi, dalam kondisi ini maka pelaku usaha harus siap dengan pemahaman bahwa dengan berdiri sebagai badan hukum akan lebih meningkatkan pendapatan dan menjamin keberlangsungan usaha kedepannya.

i. Penyusunan / Pembukuan Keuangan Bisnis/ Manajemen Pengelolaan Keuangan Bisnis;

Keberhasilan usaha akan terwujud apabila pengusaha dapat mengelola dan penyusunan pembukuan keuangannya, sebab perputaran keuangan akan memberikan gambaran keberhasilan penjualan pada hari tertentu. Kemudian pemisahan keuangan pribadi dan keuangan adalah mutlak diperlukan, sebab pemisahan akan memberikan pendidikan tentang bagaimana mengelola keuangan pribadi dengan tanpa tercampur dengan keuangan perusahaan atau usaha.

j. Desaian Kemasan dan Eco Label;

Setelah produk mengalami peningkatan maka desaian kemasan dan eco label yang ramah lingkungan juga sangat dibutuhkan, sebab dalam perkembangan kedepan setiap pengusaha juga harus memperhatikan keberlangsungan lingkungan demi warisan sumber daya alam untuk anak cucu kedepan nantinya.

k. Karaktrer Pengusaha;

Sebagai seorang pengusaha tentu akan mengalami berbagai ujian dalam menjalankan bisnisnya, maka seorang pengusaha harus memiliki karakater tahan banting dengan segala kendala yang dihadapinya.

\section{Tahapan Pendampingan}

a. Pengurusan Nomor Pokok Wajib Pajak (NPWP) Orang/ Pribadi;

b. Pengurusan Nomor Induk Berusaha- Industri Usaha Kecil Menengah (NIB-IUMK), dalam pendampingan ini setiap pelaku usaha mendaftarkan produk usahanya secara online ke dalam sistem yang telah disediakan oleh Negara yaitu : app.oss.go.id.

c. Pengurusan Sertifikat Penyuluhan Ketahanan Pangan, untuk mendapatkan sertifikat ini pelaku usaha wajib mengikuti pelatihan dan tes tertulis yang langsung dilaksanakan oleh Dinas Kesehatan Kabupaten Kampar, dalam pelatihan ini pelaku usaha diberikan edukasi tentang produk apa saja yang baik untuk makanan lopek bugi serta makanan apa yang tidak boleh digunakan, sebab kelebihan takaran ukuran produk akan berdampak kepada konsumen yang mengkonsumsinya;

d. Pengurusan Sertifikat Produk Industri Rumah Tangga (P-IRT); PIRT adalah sertifikasi perizinan bagi industri yang memproduksi makanan dan minuman rumahan, sertifikat ini di kelurkan oleh Kantor Pelayanan Terpadu/ Kantor Perizinan Kabupaten Kampar berdasarkan rekomendasi Puskesmas Tambang, dan Dinas Kesehatan Kabupaten Kampar;

e. Praktek Inovasi Lopek Bugih berbagai inovasi rasa, yaitu Rasa Nenas, Rasa Jangung Kelapa, Rasa Gula Merah, Rasa Durian, dan Rasa Strowberi, dengan protokol kesehatan yang ketat pelaku usaha secara bersama sama melakukan pratek langsung beberapa varian rasa lopek bugih.

\section{Tahapan Rencana Tindak Lanjut}

Dalam tahapan ini, pelaku usaha lopek bugih sudah mampu dan memahami tentang manfaat adanya legalitas usaha, sebab memiliki legalitas sama saja memiliki identitas kepemilikan usaha yang dapat dipertahankan terhadap siapapun yang ingin menguasainya secara illegal, kemudian dalam inovasi lopek bugih pelaku usaha telah memiliki kekayaan macam dan bentuk produknya, sehingga dalam proses perjalanan 
usahanya mereka dapat mengembangkannya dengan selalu berinovasi baik itu rasa, bentuk, dan kemasan. Inovasi usaha mutlak sangat diperlukan sebab perkembangan zaman dan waktu dengan sendirinya akan membentuk karakter konsumen itu sendiri yang memerlukan hal-hal yang baru dan viral.

Rangkaian kegiatan rencana tindak lanjut ini akan dilaksanakan pada tahun berikutnya sehingga setiap pelaku usaha akan memiliki izin halal dari Majelis Ulama Indonesia (MUI), adanya izin ini memberikan nilai lebih terhadap produk yang dihasilkan, begitu juga konsumen akan merasa lebih nyaman dan aman untuk mengkonsumsi produk-produk lopek bugih tersebut.

Pemberdayaan masyarakat Desa Palung Raya, khususnya pelaku usaha lopek bugi bertujuan untuk :

1. Menciptakan suasana yang memungkinkan berkembangnya potensi/ daya yang dimiliki masyarakat;

2. Memperkuat potensi/daya yang dimiliki masyarakat;

3. Melindungi masyarakat melalui pemihakan kepada masyarakat yang lemah;

4. Menciptakan kesejahteraan masyarakat yang nyata dan berkesinambungan;

5. Menciptakan masyarakat yang mandiri dan mampu berkarya sesuai dengan kemampuan dan potensi keluarganya.

Program pemberdayaan pelaku usaha lopek bugih pada saat sekarang ini sangatlah penting, hal ini bertujuan untuk meningkatkan kualitas usaha itu sendiri melalui berbagai hasil variasi produk yang lebih inovatif dan peka terhadap pertumbuhan ekonomi pedesaan serta membangun kapasitas pasar produk itu sendiri yang berkelanjutan untuk meningkatkan kesejehteraan sosial-ekonomi masyarakat dan kemandirian Desa, sesuai dengan arah dan kebijakan Presiden Jokowidodo.

\section{KESIMPULAN}

Pengabdian Kepada Masyarakat Program Desa Binaan Universitas Riau merupakan wujud nyata perguruan tinggi dalam memberikan pelayan kepada masyarakat, khususnya bagi pelaku usaha lopek bugi yang ada di Desa Palung Raya Kecamatan Tambang Kabupaten Kampar. Kegiatan ini merupakan solusi dari permasalahan yang ada pada pelaku usaha lopek bugi yang selama ini tidak dapat menembus pasar modern yang disebabkan belum adanya izin atau legalitas usaha yaitu: Pengurusan Nomor Pokok Wajib Pajak (NPWP) Pribadi, Pengurusan Nomor Induk Berusaha Izin Usaha Mikro Kecil (NIB-IUMK), serta Pengurusan Sertifikat Produk Industri Rumah Tangga (P-IRT), serta menciptakan berbagai inovasi produk lopek bugih yang sebelumnya hanya teridiri dari rasa original dan pulut hitam untuk tahun ini telah menghasilkan berbagai inovasi rasa, yaitu Rasa Nenas, Rasa Jangung Kelapa, Rasa Gula Merah, Rasa Durian, dan Rasa Strowberi.

\section{UCAPAN TERIMAKASIH}

Terimakasih diucapkan kepada Lembaga Penelitian dan Pengabdian Kepada Masyarakat Universitas Riau (LPPM UNRI) yang telah mendanai kegiatan Pengabdian Kepada Masyarakat ini, yaitu dengan Nomor Kontrak: 909/UN.19.5.1.3/PT.01.03/2020. Kemudian tidak lupa juga kami ucapkan terimakasih kepada Kepala Desa Palung Raya Kecamatan Tambang Kabupaten Kampar, Dinas Kesehatan Kabupaten Kampar, Dinas Perdagangan dan Usaha Mikro Kecil Kabupaten Kampar, Puskesmas Tambang, Mahasiswa Kuliah Kerja Nyata, Pelaku Usaha Lopek Bugih dan masyarakat Desa Palung Raya Kecamatan Tambang, Kabupaten Kampar.

\section{DAFTAR PUSTAKA}

Adjie Priambada, Arti Hak Kekayaan Intelektual bagi Starup dan Usaha Kecil Menengah, https://dailysocial.id/post/hkistartup-ukm diakses pada 9 Oktober 2020.

Andrian Gunandi, Potensi Bangkit UMKM dan Industri Kreatif melalui Peer to Peer Landing, https://ekonomi.kompas.com/read/2017/04/04/123000526/potensi-bangkitnya-umkm-dan-industri-kreatifmelalui-peer-to-peer-lending- . diakses pada 9 Oktober 2020.

Anwas M. Oos, 2014. Pemberdayaan Masyarakat Di Era Global. Bandung. Alfabeta.

Raffana, Patta, Zulfikry Sukarno, 2017. Ekonomi Pembangunan. Makassar. CV. SAH MEDIA.

Munawar, N. 2011. Jurnal Ilmiah CIVIS. 1(2).

Departemen Pendidikan Nasional. 2003. Kamus Besar Bahasa Indonesia. Jakarta. PT.Balai Pustaka.

Undang-undang Nomor 32 Tahun 2004 Tentang Pemerintahan Daerah. 